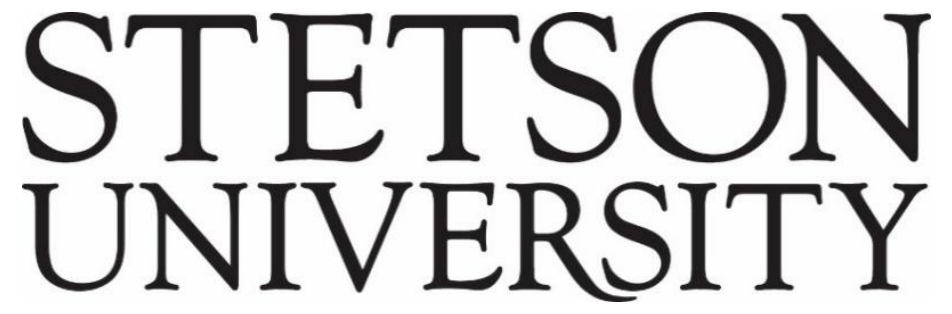

Voices of Reform: Educational Research to Inform and Reform

Volume $1 \bullet$ Issue $1 \bullet$ Article 7

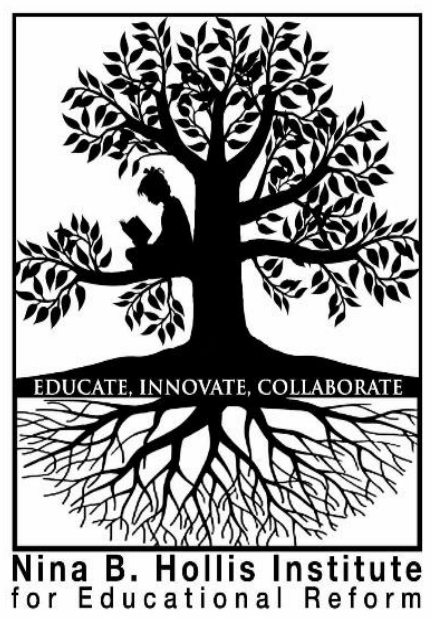

September 2018

\title{
After the Storm Comes the Rainbow: Love, Home, and Permaculture in Puerto Rico
}

Ronald K. Porter

Eckerd College

Follow this and additional works at: http://www.voicesofreform.com

Recommended Citation

Porter, R. (2018). After the storm comes the rainbow: Love, home, and permaculture in Puerto Rico. Voices of Reform, 1(1), 99-106. Retrieved from https://www.voicesofreform.com/article/4489-after-the-storm-comes-therainbow-love-home-and-permaculture-in-puerto-rico. doi: 10.32623/1.00009

http://dx.doi.org/10.32623/1.00009

Revisions

Submission date: June $1^{\text {st }}, 2018$

$1^{\text {st }}$ Revision: July $10^{\text {th }}, 2018$

Acceptance: July $17^{\text {th }}, 2018$

Publication date: September $15^{\text {th }}, 2018$ 


\title{
After the Storm Comes the Rainbow: Love, Home, and Permaculture in Puerto Rico
}

\author{
Ronald K. Porter ${ }^{1}$ \\ ${ }^{1}$ Director of Service Learning \\ Eckerd College, United States \\ porterrrk@eckerd.edu
}

\begin{abstract}
For the past several years, Eckerd College has maintained a relationship regarding community engagement with Plenitud, an eco-educational organization located in Las Marias, Puerto Rico specializing in permaculture, bio-construction, and sustainable community service projects. However, the purpose and nature of our relationship changed following the aftermath of Hurricanes Irma and Maria. Whereas concern over risk management and general safety are always a priority when planning an alternative spring break service project, the media's depiction of visions of an apocalyptic Puerto Rico with no food, water, energy, or decency had made the task even more difficult. This article chronicles the challenges and celebrations of creating such a trip, and the impact traveling to Puerto Rico to participate in hurricane relief work had on the local community in Puerto Rico as well as Eckerd College students. The hope is that as practitioners of service-learning we can begin to pose questions regarding where we are most needed and what actually accounts for meaningful service.
\end{abstract}

\section{Keywords}

Puerto Rico, hurricane, permaculture, service learning

\section{Introduction}

It all started with an unexpected conversation in the fruit section of the grocery store. "Are you still going to Puerto Rico?" "Yes," I said, "why do you ask?" "Oh, I do not think you should go with students, it is not safe." I had been to Puerto Rico before, and I had heard the same precautionary thoughts on the dangers of the island. "It's not safe, there are a lot of gangs, and Zika" was the mantra repeated again and again before a previous trip to Plenitud, a permaculture and sustainable agriculture farm located in the mountains of Las Marias on the West Side of the island. Being no stranger to travel, I also know too well the societal notion of "western human 
safe, everything else questionable," even if "everything else" includes American citizens (Osamu, 2006). However, the fears of gangs, robbery and disease were exacerbated by the glancing blow of Hurricane Irma and the direct wrath of Hurricane Maria in September 2017. Whereas concern over risk management and general safety were always on my mind when planning an alternative spring break service project, the media's depiction of visions of an apocalyptic Puerto Rico with no food, water, energy, or decency had made my task even more difficult. How was I supposed to get 11 students safely there and back, and was I being a fool for going in the first place? What is our responsibility as educators and college students in helping others in need in an ever-shifting world? Why did that woman randomly tell me not to go to Puerto Rico in the grocery store? I had to consider, were these bad omens? Nevertheless, through research, logistics, and risk management reviews the student trip leader, Adam Maxwell, and I trudged on, realistically assessing the situation but also fully aware that we were traveling to a place that needed our help and dollars. Little did I know that the process of developing this trip and moving beyond the stigma unduly placed upon Puerto Rico would end up being a beautiful life changing experience for all participants.

\section{Love, Home, and Permaculture: Plenitud Iniciativas Ecoeducatives}

Founded in 2010 by Paula Paoli-Garrido and Owen Ingley, Plenitud teaching center is an ecoeducational organization located in Las Marias, Puerto Rico that specializes in permaculture, bioconstruction and sustainable community service projects. According to Paoli-Garrido and Ingley, "Permaculture is a design system for the conscious creation and maintenance of agriculturally productive ecosystems and human habitats, which have the diversity, stability, and resilience of natural ecosystems. It is a holistic science that harmoniously integrates landscape and people, providing water, food, energy, shelter and other material and non-material needs while benefiting the environment" (personal communication, May 29, 2018).

The center is dedicated to the research and demonstration of organic agriculture and sustainable practices. "Permaculture" design principles, emphasizing soil conservation, responsible water management, renewable energy, and natural building have primarily guided the layout, methodology, and development of the farm. According to Paoli-Garrido, "We believe the underlying source of much of the world's unrest involves a fundamental detachment from natural cycles, a shortsighted understanding of interconnections, and a misguided sense of our responsibility in the world. A fundamental shift in how we relate to ourselves, each other, land and resources, food, education, health, and more, is indispensable to create healthy human communities and societies, now and in the future" (personal communication, May 29, 2018). Groups have the opportunity to visit the farm and participate in workshops focusing on natural building, rainwater harvesting, organic gardening, aromatherapy, vegetarian cooking, and yoga. Service, including garden and crop maintenance, compost management, and educational art projects, is done on site or within the community with local farmers and schools.

Eckerd College has had a long-standing relationship with Plenitud. The organization has been a primary partner in the development of the Reflective Service Learning program and Eckerd College has sent a spring break service project to Plenitud for the past 7 years. Students at Eckerd College are required to complete 40 hours of Reflective Service-Learning in order to graduate. 
They do this by taking an academic Reflective Service-Learning course, which includes service as part of the course curriculum. Students can also complete an independent service project. Alternative Spring Break Projects allow students the opportunity to earn Reflective ServiceLearning hours. Students are required to reflect upon their experience during the trip and complete a written reflection after the trip.

Eckerd projects have usually focused on students learning about permaculture, and helping construct community gardens at local schools. Eckerd College students have benefited from service at Plenitud in multiple ways, from having hands on experience with sustainable gardening practices to pursuing internships at Plenitud at the completion of graduation. One way that I have witnessed involved what I call, in a yogic sense, uniting the head and the heart, or the mind and the body. Students who have traveled with me to Plenitud are at first awed by the landscape, being able to eat off the land, and getting their hands dirty building terraces. They are then physically and mentally bewildered by the lack of access to technology and getting more into bodily sensation through yoga or working on the farm. However, what also comes up in the midst of this awe and bewilderment is a great deal of anxiety and uneasiness about the future, on the personal and global levels. As one student asked me, "Dr. Porter, how do you stay so happy when there is so much pressure on us all the time?" Getting away from the setting of a college campus, computer, and a phone for just a week allows students to critically reflect on what is really important in their lives, to pause and become introspective. Through service, discussions, dance, yoga, and living in this new community, students question the notion that our relationship to the environment is limited to the "natural world." Plenitud allows us to investigate how our mental, physical, and spiritual relationship to the environment impacts the choices we make in our lives and overall human flourishing.

\section{Entering the Eye of the Storm: The Impact of Hurricane Maria}

On September 20, 2017, Hurricane Maria devastated the island of Puerto Rico as a category 4 hurricane. The first category 4 storm to hit Puerto Rico in 85 years, the storm left much of the island of over 3 million people without power for months. The original death toll from the disaster was 64. However, a recent Harvard study estimates that the death toll may have been over 4,000 people (Fink, 2018). While weak infrastructure has been blamed for the ferocity of the damage, the impact of a category 4 storm would be devastating to most areas. Eckerd College had planned a service trip to Plenitud well before hurricane season began. The devastation from the storm caused many persons, including myself, to question whether going to participate in service was worth the risk of our safety. With reports that $100 \%$ of the island's power was down, and the director of Puerto Rico's emergency management agency stating that the island had been "destroyed," it was easy to believe that our service trip would have to be canceled (Schmidt, Achenbach, \& Somashekhar, 2017). But what was worse is that we had no way to communicate with our friends at Plenitud. We had no idea of knowing whether they were alive or dead. An administrators concern for safety was contrasted with the feeling that the people of Puerto Rico had been left alone to fend for themselves in the dark.

It took several weeks to finally establish communication with our friends at Plenitud. I thought the news would be grim, but when I spoke to Owen and Paula they were optimistic and excited. 
This was a huge difference from what folks on the mainland were seeing in the media. To my surprise, Owen said that due to the permaculture design systems implemented at the farm over the years they weathered the storm very well. Everyone at the farm was healthy, happy, whole and eager to have volunteers come down. Owen mentioned that, contrary to media reports, the people of Las Marias had come together as a community to assist each other in the storm. In my skepticism, I immediately believed that this good news was Plenitud's naiveté. In time, I would find out that not only had Plenitud weathered the storm quite well, but also their permaculture methods, once questioned in their community by local farmers, were gaining interest in the community due to the fact that Plenitud was not experiencing devastating landslides and rainwater harvesting allowed them access to water. What was beginning to shine through was that this storm may have ended up being a teaching moment for cultivating a good relationship with the land and local community.

\section{Planting the Seeds: Establishing an Environmental and Holistic Consciousness}

In spite of my conversations with friends at Plenitud, I was still very skeptical about taking students to Puerto Rico. Luckily, prior to the hurricane Eckerd College had invited Owen and Paula to give a talk on Plenitud and how they established their farm. Initially, we invited Paula and Owen because Eckerd has many Environmental Science and Studies majors who are interested in starting environmental nongovernmental organizations, eco-villages, and holistic education centers. Having Plenitud come to Eckerd College would be a wonderful opportunity for these students to meet individuals who have actually made such a vision a reality, and to learn about the celebrations and challenges involved in such an endeavor. However, in the aftermath of the hurricane I was doubtful that Paula and Owen would even be able to make it to the airport in San Juan, let alone still have an available flight. Again, my skepticism was challenged as our friends at Plenitud made the journey and gave an outstanding presentation for our students, and a permaculture consultation at the Eckerd College garden. They also gave a firsthand account of the hurricane, "Imagine one day you wake up and you have no cell phone reception, no water, no electricity, no mobility and you feel completely isolated. The hurricane really tested our systems and created a very unique opportunity to come together with our community and neighbors to survive a very difficult situation" (Paoli-Garrido \& Ingley, 2017). Paula and Owen visiting campus emphasized the help needed in Puerto Rico. There was now a sense of urgency, as student leader Adam Maxwell stated, "I was more motivated to go. I felt like it was much more important than in previous years" (personal communication, May 29, 2018). I worked closely with Plenitud throughout the winter to make sure they were well prepared for our visit. Thankfully, by March 2018 we had been cleared to go.

On March 17, 2018, I traveled with 11 students to Puerto Rico to not only learn about permaculture, but also to assist in any way we could with hurricane relief. Naturally, we all felt like we could only do so much being there for a week. Nevertheless, I told the students that service is not only about doing manual labor: it is also about spreading the light of joy within dark situations. Our presence on the island would be a healthy medicine for the community. As we landed in San Juan, one student observed that many of the buildings had blue roofs. I noted that those were probably FEMA tarps, and conveyed that we need to be prepared for what we would see in terms of damage. 
My awareness was still heightened, as I was not totally sure what we would encounter. However, once we landed everything seemed to flow together. The media had portrayed Puerto Rico as a broken place full of desperation. While it was clear that people had gone through an extremely challenging situation, spirits were not broken and progress was being made.

Once we arrived at Plenitud, I knew we had made the right decision to come. We worked as community ambassadors, dancing at a local festival attended by thousands and attending a Zumba class taught in the local community. Students worked extremely hard to repair damaged crops not only at Plenitud, but also at the farms of local community members. We were able to assist Luis Soto, a leader of the organic farming movement in Puerto Rico whose farm was almost completely destroyed by the hurricane. Reflecting on her experience, student Claudia Colon wrote:

The fourth day, our job took place at Tío Luis' farm. His farm was completely destroyed by hurricane Maria and Plenitud has been helping him re do his farm ever since... When we arrived, Tío Luis happily let us in and explained a little about his farm and his life. His name is Luis and he is almost eighty years old. He builds and modifies all the tools that he uses in his farm. His farm does not contain any type of machinery nor chemicals. After his introduction, it was time to get to work. My job was to clear [the area] between the crop and the fence. I had to remove all the bad grass growing and even out the dirt. After finishing our jobs, Tío Luis came to look how it turned out. He got so happy that his eyes watered. Looking at him made me cry of happiness because I felt like I really helped someone that one day had everything and the next had nothing. I realized that I really do enjoy making other people happy no matter how much effort it takes. (Eckerd College Reflective Service-Learning Co-Curricular Reflection)

Throughout our journey, I was moved by how thankful people were that we were just there. As we sat together cleaning loads of fresh turmeric and basil a student from the University of Puerto Rico at Mayagüez told me, "We need you down here, thank you so much for coming." It was confirmed for me at that point that we had made the right decision to come to Puerto Rico both for the students and for Plenitud. Reflecting of the changes he experienced while on the trip, a student recalled, "I think the biggest change was within the group as a whole. Through service we became more confident as a collective to reach out and lend a helping hand."

\section{Spreading the Light}

In the aftermath of Hurricane's Irma and Maria, the strength and will of millions of people on the island of Puerto Rico was put to the test. Our journey to Plenitud highlights the progress made, but it should not detract from the suffering inflicted by these storms. In the wake of this journey, questions arise. Balancing the need to follow risk management procedure, what is the role of college students in performing community service in locations or with persons who have been stigmatized or labeled dangerous? What is the responsibility of colleges and universities in responding to large-scale disasters? How does implicit bias impact who receives help in the wake of such disasters? There exists a necessary friction between the academy and community, and as more colleges and universities develop community engagement programs, perhaps our greatest challenge and moment of growth will be in a new understanding of an institution's place within 
and as part of communities. In other words, how service learning changes the individual and effects their learning goals and relationship to the community.

The partnership between Eckerd College and Plenitud has been greatly strengthened through our service project. Highlighting the impact of our trip, Owen affirmed, "The service-learning trip from Eckerd helped Plenitud to continue to recover from the impact of the hurricane on the educational farm, as well as strengthened our relationships with neighboring farmers" (personal communication, May 29, 2018). Since our visit, Plenitud has worked to organize a series of health clinics and workshops in collaboration with the local government and medical officials. With the help of Eckerd interns and volunteers, Plenitud has distributed over 2000 water filters and has provided training in the community on emergency water filtration. My hope is that the destruction caused by these devastating storms can provide an opportunity for growth and change. I am so thankful that Eckerd College was able to assist in this opportunity and will continue to do so for years to come. Perhaps, through entering into challenging situations with an open mind, and open heart, and a willingness to help we can all, in the words of one of my students, "see the power of community to change the environment for the better, for everyone!"

\section{References}

Fink, S. (2018, May 29). Puerto Rico's Hurricane Maria death toll could exceed 4,000, new study estimates. New York Times. Retrieved from https://www.nytimes.com/2018/05/29/us/puerto-rico-deaths-hurricane.html

Osamu, N. (2006). Anthropos and humanitas: Two western concepts of "Human Being." In N. Sakai \& Jon Solomon (Eds.). Translation, Biopolitics, Colonial Difference (pp. 259-273). Hong Kong, China: Hong Kong University Press.

Paoli-Garrido, P. \& Ingley, O. (2017). Love, home, \& permaculture: Plenitud farm Puerto Rico. Lecture presented at Eckerd College, St. Petersburg, FL.

Schmidt, S., Achenbach, J., \& Somashekhar, S. (2017, September 20). Puerto Rico entirely without power as Hurricane Maria hammers island with devastating force. The Washington Post. Retrieved from https:/www.washingtonpost.com/news/post-nation/wp/2017/09/20/hurricane-maria-takes-aim-at-puertorico-with-force-not-seen-in-modern-history/?noredirect=on\&utm_term=.ac11b21b79c8 


\section{Appendix A}

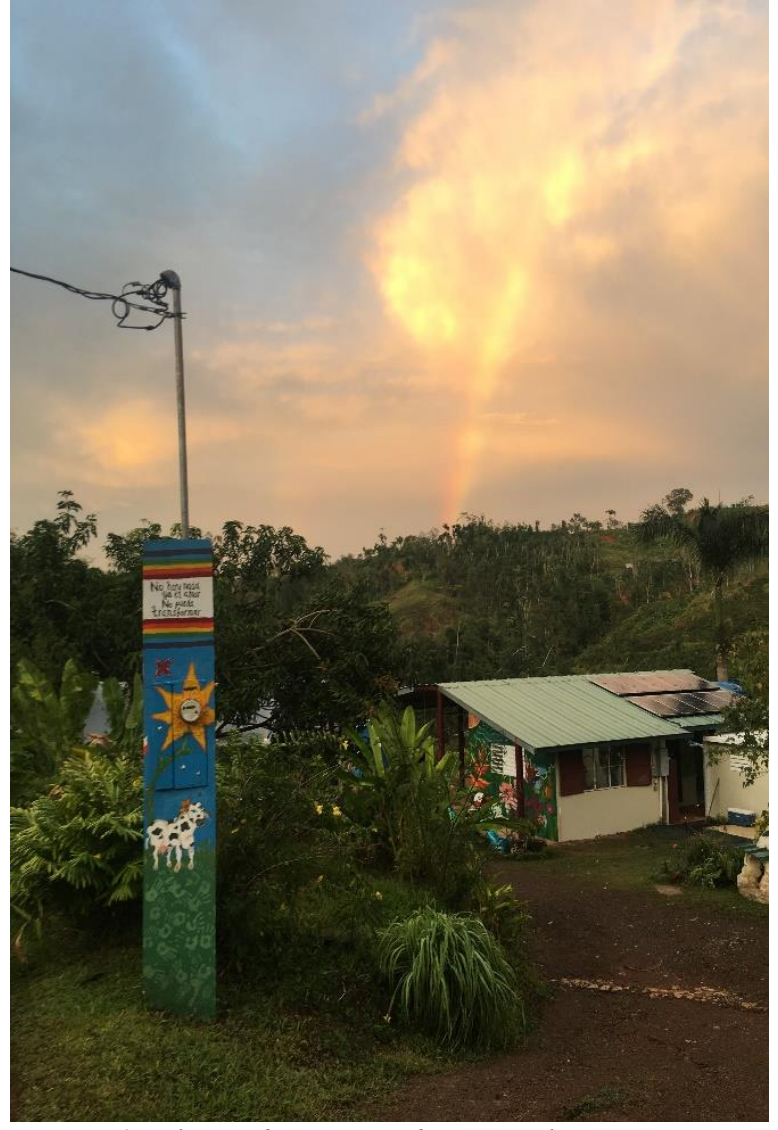

Figure 1: Plenitud, an eco-educational organization located in Las Marias, Puerto Rico.

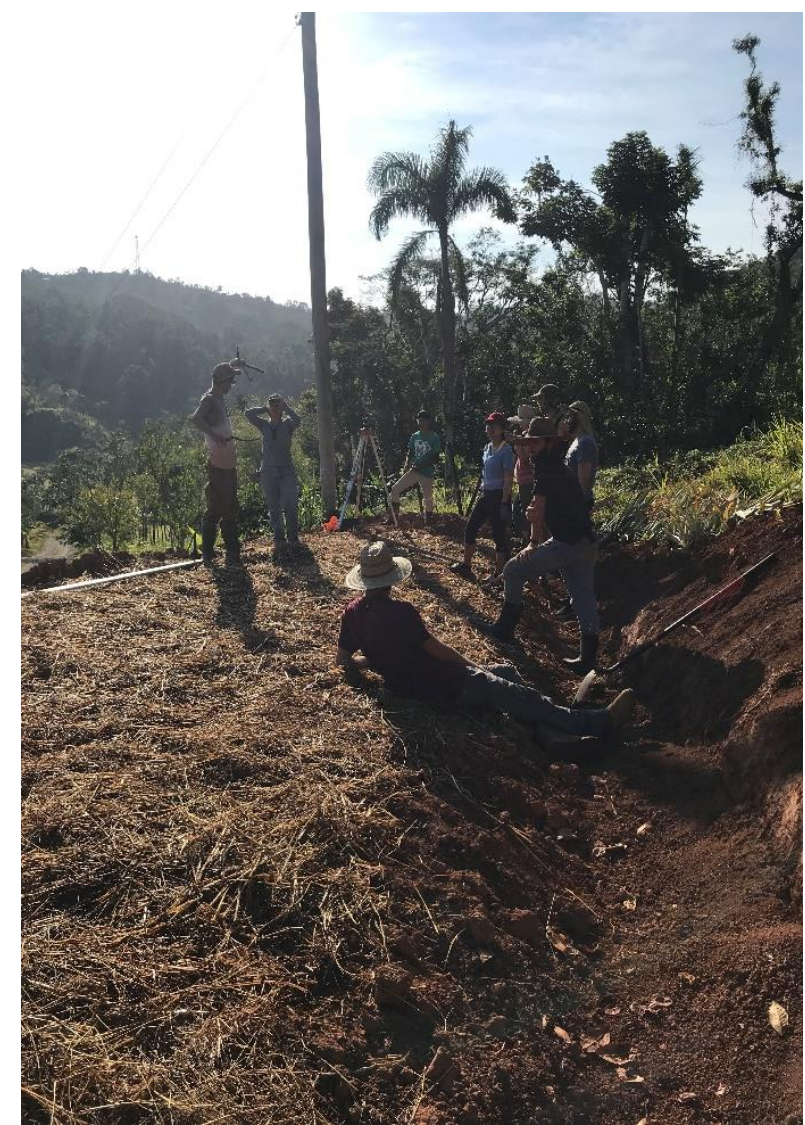

Figure 2: Eckerd College students working on terraces as part of permaculture design at Plenitud, Puerto Rico. 


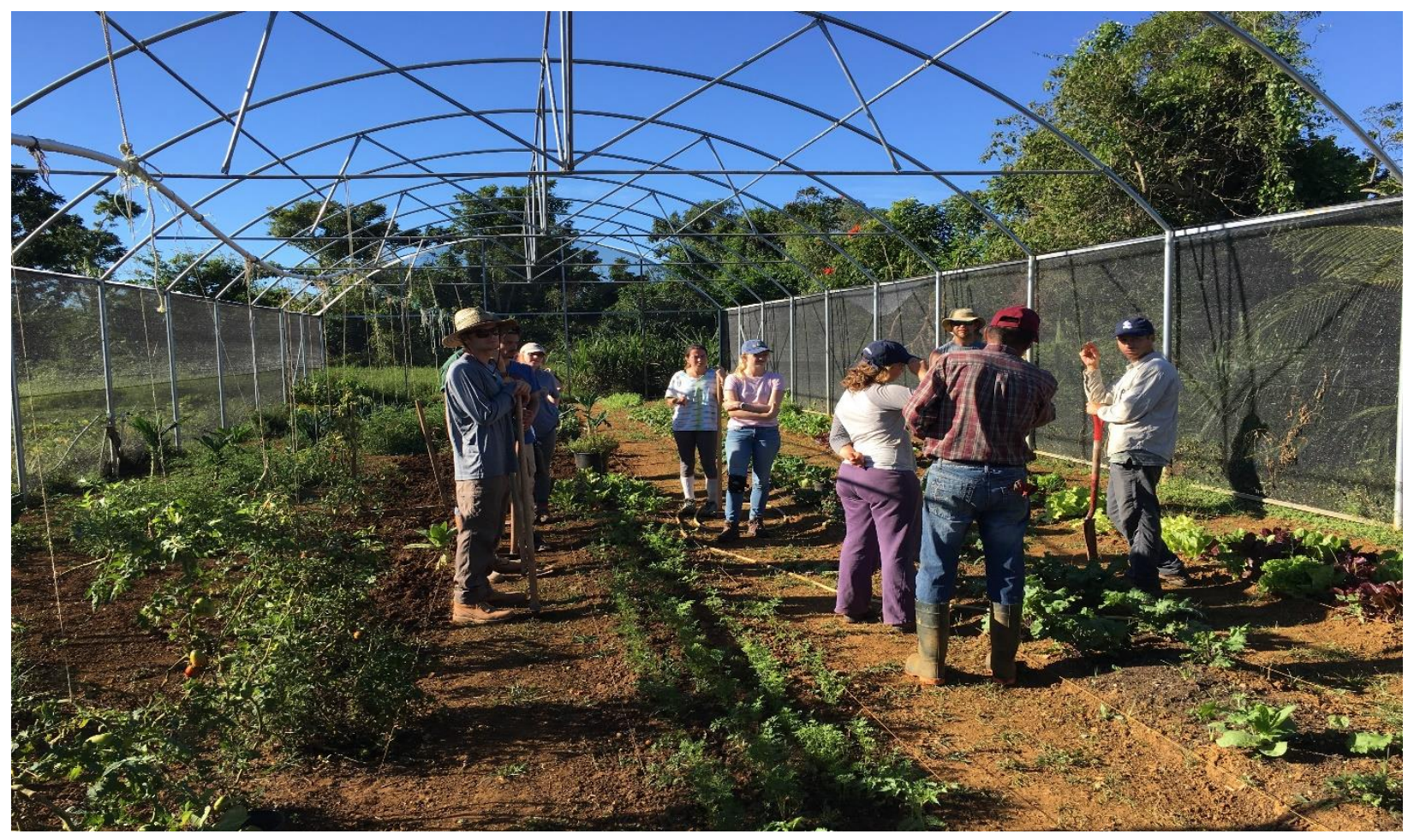

Figure 3: Eckerd College students helping assist Luis Soto, a leader of the organic farming movement in Puerto Rico whose farm was destroyed by the hurricane.

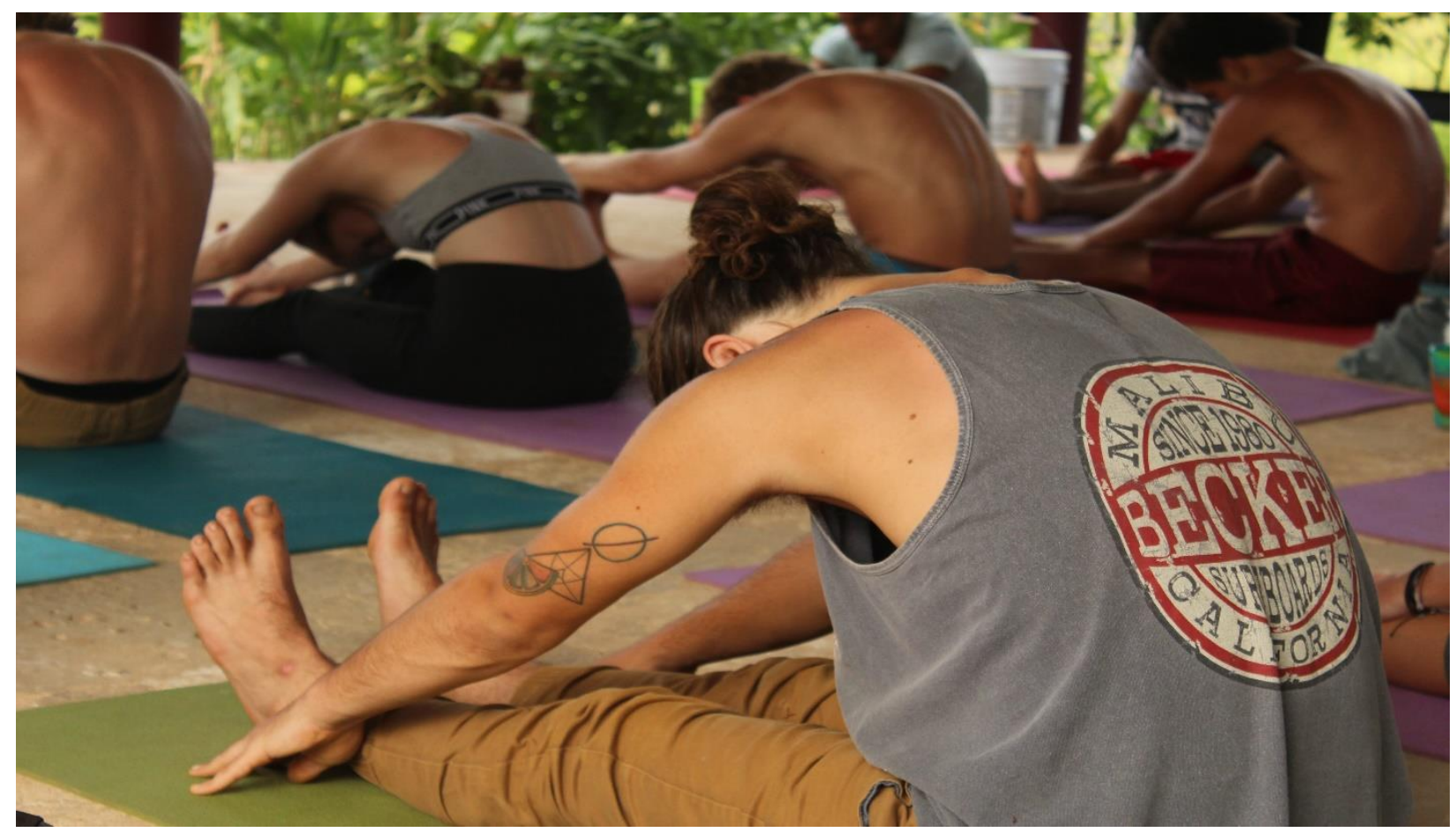

Figure 4: Eckerd College students participating in daily yoga at Plenitud, Puerto Rico. 